\title{
A Socio-Pragmatic Study of the Nigerian National Anthem
}

\author{
Idowu O. Odebode, PhD, MA, BA. ED, PGD \\ Redeemer's University, Nigeria
}

Doi: 10.19044/llc.v7no3a2 URL:http://dx.doi.org/10.19044/llc.v7no3a2

\begin{abstract}
This study aims at unearthing the language of the Nigerian national anthem (Arise $\mathrm{O}$ compatriots) from a socio-pragmatic perspective. The research is grounded on three theoretical frameworks namely, Austin's (1962) speech act theory because words perform actions in different socio-cultural contexts; Giles, Coupland and Coupland's (1991) accommodation theory because communication is a matter of convergence and divergence in the socio-cultural milieu and Halliday's (2004) systemic functional grammar because words are arranged systematically to make meanings. They possess ideational, interpersonal and textual capabilities. The study, which is born out of the dearth of linguistic research on the Nigerian national anthem, indicates that the (new) Nigerian national anthem is not just designed as an ordinary political song. It is intended for praying and informing; hence, its major illocutionary acts. The writer/composer also deploys asserting, summoning, and admonishing as the song's minor illocutionary acts, to advise the citizens on their historical antecedents and declare their duties to the nation. A further classification of the textual verbs according to Austin's paradigm indicated that the song is inundated with behavitive, excersitive and verdictive speech acts.
\end{abstract}

Keywords: Nigeria, National Anthem, Pragmatic Act, Socio-pragmatics.

\section{Introduction}

Like a country's motto, flag, or crest, a national anthem symbolizes the essence of a nation. It is also blessed with subtle and coded historiography of the country. The song is sung daily in schools, on radio/television and at official functions in which the head of government or his representative is present. It is regarded as a means of patriotism to one's nationality. Based on the above, Faniyan (2012) submits as follows:

A national anthem is a solemn patriotic song adopted as an expression of national identity. It is a tool to endear the idea of a fatherland to the hearts 
of citizens. A device to make the country a part of the people that are named after it.... a creed to inspire virtues such as loyalty, service, and a sense of belonging to one's country. It inspires love, unity and courage in the face of unfavourable circumstance (Faniyan, 2012:1).

One unique characteristic of national anthems is that they are carefully constructed in a "semantico-syntactic sense to manifest specific meanings" (Oyeleye 1985, p.138). Therefore, our preoccupation in the present study is to analyse the (new) Nigerian national anthem from a socio-pragmatic perspective. This is with a view to unravel its (sociolinguistic as well as pragmatic) imports via the principle of speech act, accommodation theory and aspect of systemic functional grammar. Studies on Nigerian national anthem have not enjoyed quantitative attention from linguistic scholars. But for Faniyan (2012) and Oyeyemi (2018), most research works (e.g. Mohammed and Ayeni, 2018) on this important linguistic domain have approached it from the socio-political point of view. The present study is an attempt at filling this gap.

\section{The Nigerian National Anthem:}

"Arise O Compatriots" is the national anthem of Nigeria, a former colony of the British and the most populous country in Africa, seventh in the world. It has an estimated population of over 200 million people, with 90 million of its population under the age of eighteen. This makes the country to have the third-largest youth population in the world, after India and China. (see

https://www.google.com/search?client=firefoxd\&q=nigeria+the+most+popul ous+country+in+africa). The country has about 450 ethno-linguistic groups. Among these, the trio of Hausa (North), Igbo (East) and Yoruba (West) stand out. Politically, the song brings about unity among the heterogeneous communities/languages in Nigeria. That is why it is largely sung in English, the official language (cum lingua franca) of the country. At the inception, it was translated to only the three dominant languages (Hausa, Yoruba, Igbo) locally. But unlike English, the languages cannot sustain cohesion in the diverse situations. The song, therefore, is one of the cords that bind Nigeria together as a nation, hence its importance to the present study.

Before independence in 1960, the patriotic song of Nigeria was the British "God save the Queen". When the Union Jack was lowered and Nigeria became independent on October 1, 1960, the country changed its anthem to "Nigeria we hail Thee" (1960-1978). It was composed by a Briton, Miss Frances Benda. In the quest to reclaim its identity, Nigeria changed to a new anthem, "Arise O Compatriots." It was produced by a native Police Officer, Benedict Odiase and adopted in 1978 to replace the previous song. 


\section{Literature Review:}

Several studies have been carried out on political discourse. One of them is Adegbite (2009) does an expose on politics and political discourse. Citing Chilton (2004:4), he views politics as a struggle for power between the intending rulers who seek to assert and maintain their power and those who are opposed to such move on one hand. On the other hand, politics is considered as "co-operation in the sense of practices and institutions that a society has for resolving clashes of interest over money, influence, liberty and the like." (Adegbite 2009:10). However, language is crucial to power negotiation and the sustainability of cooperation among social institutions. Therefore, political language should, first of all, be considered as discourse before being viewed as politics. The work is related to the present study because our focus is on the Nigerian national anthem as a (political) discourse. It should be noted that "Arise O compatriots" is a Nigerian national anthem which was designed in the post-independence era as an instrument of cooperation among the citizens. It also serves as a means of reclaiming identity and rejecting colonial mentality (enshrined in the previous anthem composed by the British).

One of the pioneering works on the Nigerian national anthem is Faniyan (2012). The author takes a stylistic approach to study both the Nigerian national anthem and pledge simultaneously. He discovers that graphologically, the author uses 118 words for the national anthem for ease of remembrance. But at the level of grammar, the composer of the national anthem and pledge subvert the syntactic rule by not sticking to the traditional SVOCA rule throughout the composition. He maintains that the word "arise" is a call to action lexically and contextually.

The work updates our knowledge of the Nigerian national anthem from another perspective, i.e., stylistics. Its combination with the pledge makes the analysis inadequate and less rigorous. Moreover, because of the nature of the approach, i.e., stylistics, the author dwells more on syntactic and graphological analysis. The present study takes care of these shortcomings, and it takes a socio-pragmatic approach to the study of the national anthem without combining it with the pledge such that the analysis can be thorough.

In a related research, Mohammed and Ayeni (2018) take a critical look at the challenges before past, present and future Nigerian political leadership using the national anthem and national pledge as their symbol and corpus for analysis. They discover that mismanagement of resources coupled with protracted military intervention has affected the vision of the founding fathers of the country. This really negates the oaths sworn to by the rulers and the wordings of the song "to serve our fatherland with love and strength and faith." The study views Nigeria's problems from the political perspective while using the national anthem and the pledge as a corpus. It is thus related to the present 
study in data but differs in approaches. While the current study uses the linguistic approach, Ayeni and Mohammed's (2018) work uses a political approach.

Besides, Odebode and Okunlola (2018) consider Goodluck Jonathan's inaugural speech from a pragmatic perspective. The speech act theory by Austin (1962) is invoked and tested on the data. The analysis indicates that informing has the highest illocutionary frequency. This is followed by acknowledging, thanking and motivating, respectively. The work is similar to the present in theoretical framework because speech act theory is one of the theoretical preliminaries adopted for benchmarking the present study. However, the study differs from the present in data. While it analyses the speech of the former president of Nigeria, Goodluck Jonathan, the present study has Nigerian national anthem as its corpus.

Furthermore, Ogunsiji (2018) studies the power and politics of language. He submits that in Nigeria, English is a language of power because it is the language of administration. He further posits that as a system of symbols, language is a powerful weapon employed by its users to manage strategic interactions in a multilingual society like Nigeria. He maintains that the poor management of linguistic diversity in Nigeria is a curse rather than a blessing. Consequently, he dissects language into micro and macro levels. These two have a symbiotic relationship in that the linguistic power possessed by an individual (micro-level) does affect the operation of language at the larger society (macro-level). Linguistic exchanges, therefore, become the instrument of power relations and negotiations in the human sphere. At this juncture, this study argues that the composer of the Nigerian national anthem has deployed language at the micro-level such that the song's messages affect the larger society at the macro level. Therefore, the writer/composer, through the song (Arise $\mathrm{O}$ compatriots), has succeeded in wrestling the power (of composing anthem) from the colonial masters who gave the country her initial anthem (Nigeria we hail thee); hence the relationship of the work to the present study.

Moreover, Oyeyemi (2018) does a text linguistic exploration of the Nigerian national anthem. Using an Integrated Theory of Text Linguistic (ITTL), he discovers that there is a paradigm shift in the structure and text of the anthem. The work emphasizes the principles of grouping, prominence and cohesion, and views the anthem as a genre of poetry which is characterized by few words but expresses inexhaustible meanings. The study is similar to the present research in data but different in theory and approach. 


\section{Theoretical Approaches:}

Michael Alexander Kirkwood Halliday, in the development of systemic functional grammar (SFG), postulates that language is a system of putting words together to make meanings. Thus language users have to make choices within the available linguistic options (form) such that meaning can be generated based on the context of discourse. Halliday $(1970,2004)$ ascribes three main functions to language viz ideational, interpersonal and textual. Meanwhile, Giles et al. (1991) posit that language functions as an instrument of identity and solidarity "with or dissociation from a conversational partner reciprocally and dynamically." (Giles et al., 1991, p.2). This is what they developed into the theory of accommodation, which "strategies can characterize wholesale realignment of patterns of code of language selection, although again related to constellations of underlying beliefs, attitudes and socio-cultural conditions." (Giles et al., 1991, p.2). Accommodation theory stresses that the encoder adjusts his/her speech to accommodate the decoder, which may eventually result in convergence or divergence. Convergence occurs when speeches are moved closer to the addressee while divergence moves speech styles far apart, although the latter rarely occurs.

In the same vein, Austin (1962) submits that words do not happen in isolation. Instead, they are used to perform specific actions in a given context. This is the basis of the theory of speech acts within which Austin identifies the act of saying (locutionary act), the function of saying (illocutionary act) and the effect of saying something on the listener (perlocutionary act). Initially, Austin made a distinction between constative and performative verbs. Constative verbs are used in making statements and describing events among others while performative verbs spell out the illocutionary force of the performative clauses which are used in performing a present action. The import of this is that while certain sentences can be used in communicative encounters to report states of affairs, the utterance of some sentences should be seen as the performance of an act (Osisanwo, 2003:56). Austin (1962) finally gives a taxonomy of five speech acts summarisable in Malmkjaer (2002:490) as: verdictives (e.g. giving of a verdict), excersitives (exercising of powers as in voting, advising, warning), commissives (promising or undertaking), behavitives (social attitudes like apologizing, commending) and expositives (metalinguistic use of language as in I exemplify).

Austin's pupil, J.R. Searle (1969) digresses slightly from Austin's trifurcated speech acts (of locution, illocution and perlocution). He proposes four things a speaker does with his utterance. These are: utterance act (uttering words, morphemes and sentences), propositional act (referring and predicating), illocutionary act (questioning, ordering, stating), perlocutionary act (persuading, encouraging). Searle further introduced the condition necessary for guaranteeing the speech act, otherwise felicity conditions. 
Finally, he criticized Austin's classification on the basis of too much overlapping. Searle (1969) thus comes up with the following five categories of speech acts: assertive (affirm, allege), directives (requestives, questions), commissives (promises, offers), expressive and declaratives (effectives, verdictives).

The theories are relevant to the present study because one of the significant means through which the tripartite functions of language by Halliday, are realised is the national anthem. The anthem is inundated with ideational, interpersonal and textual functions, as will be demonstrated shortly in this analysis. Furthermore, because a national anthem is an expression of national identity (Faniyan, 2012), Nigerians believed that they needed to dispense with the old national anthem (see Appendix 2), which symbolizes colonial identity. Therefore, they embraced the new anthem (see Appendix 1) composed by a fellow Nigerian, as a means of solidarity. This affirms the words of Giles et al. (1991, p.2) that the theory of accommodation functions "... to index and achieve solidarity with or dissociation from a conversational partner reciprocally and dynamically." Moreover, the wordings of the song perform certain functions in the context of Nigerian history and socio-political landscape; hence, the relevance of the speech act theory.

\section{Data Analysis:}

At this juncture, this study attempts a line-by-line pragmatic analysis of the anthem. The first locutionary act is: Arise O compatriots, Nigeria's call obey. Contextually, the word "compatriots" presupposes that the writer/composer is a fellow citizen to the listeners (i.e. Nigerians). The addressee in this context summons his kinsmen to arise and obey the call of the country. This, therefore, attests to the words of Giles et al., (1991) that a kind of convergence occurs when speeches are moved closer to the addressee. Similarly, it corroborates the emphasis of the audience design theory which views a speaker as adjusting his/her words to suit the addressees in order to express solidarity or intimacy with them (Bell, 1984). The second clause presupposes that there is a state called Nigeria, and there is a duty for the Nigerian citizens (compatriots) to obey the call.

Furthermore, by the words "arise" and "obey," this study may infer that the writer is subtly ordering his comrades to get up and obey the country's call. Socially, the perlocutionary act of the utterance hangs on the fact that the song is sung while standing up, hence the need to arise for a purpose (i.e., to obey Nigeria's call). This also affirms the writer/composer's profession as a police officer because it is in the (para) military profession that the use of lexemes such as arise and obey is in vogue. Based on the above, this research may infer that the illocutionary act of the statement is summoning cum commanding. 
The second illocutionary act is: To serve our fatherland. By this statement, the writer/composer tries to justify the reason for summoning his fellow citizens in the first stanza. However, the use of the words "our" and "serve" are also significant in this context. The addresser uses the possessive pronoun/adjective to indicate that he belongs to the group of the addressees. This is the convergence strategy in communicative accommodation theory (CAT), where individuals adapt to each other's communicative conducts to lessen social distances. Similarly, the lexeme fatherland presupposes ownership and right, i.e., not a strange land. This is in contrast to the old National Anthem, where the last sentence of the first stanza says, "Nigerians all are proud to serve our sovereign motherland" (see https://en.wikisource.org/wiki/Nigeria_We_Hail_Thee emphasis mine). This is another means of domesticating the song by the composer who is trying to shy away from the old anthem composed by the White. Thus he carefully chooses his words (e.g. fatherland) to contrast the old song as a means of reclaiming his identity. Notice that the word "sovereign" in the old song also suggests a sense of servitude and invokes a history of colonialism.

Socially, the word "serve" in the new anthem is also indicative of military jargon in which soldiers and policemen are referred to as servicemen, hence the enactment of the writer/composer's profession in the anthem. The whole lot presupposes that there is a fatherland which should be served and the purpose of calling the addressee to arise is to serve that fatherland. The illocutionary act of the statement is thus informing.

The third datum is "with love and strength and faith." This expression is contextually grounded on the previous. It is describing how the addresser and the addressees should serve their fatherland. It can also be said to be grammatically modifying the word "serve" in the previous line. Thus, the extent of the interlocutors' service should be with love, strength and faith. The illocutionary act is, therefore, describing/informing.

A couple of lines four and five serve as our next locutionary act. The writer/composer declares that "The labour of our heroes past; shall never be in vain." This utterance invokes the listener/readers' sense of history. It presupposes that there were leaders in Nigeria; the leaders wrought exploits (by the term "labour"); hence they were heroes. The inference from the word "past" is that the said heroes have died. The heroes in this context can be assumed to be the nationalist leaders who fought for the country's independence. These include Nnamdi Azikiwe, Obafemi Awolowo and Ahmadu Bello, among others. These men, who have died, were the first president, prime minister, premier (Western Region) and premier (Northern Region), respectively, in Nigeria. The writer/composer is thus appealing to the reader/listener's sense of history. He is simultaneously asserting that they (addresser/addressees) will serve their country such that the labours of their 
past heroes will not be in vain. The illocutionary act, therefore, is reminiscing/asserting.

Meanwhile, the addresser in line six of stanza one says, "To serve with heart and might." This statement suggests a question if taken together with line one [Arise $\mathrm{O}$ compatriots]. The pertinent question that comes to mind is "why should the listeners arise?" The apt answer is "to serve with heart and might." Therefore, the writer/composer is admonishing Nigerians to serve their country wholeheartedly on the one hand. On the other, he is adducing reason(s) for calling on them to arise in line one. The illocutionary act is thus admonition/justification.

The last line of stanza one is: "One nation bound in freedom, peace and unity." The word "bound" in this context presupposes a nation that is enslaved or yoked together. It further suggests that Nigeria is a heterogeneous community which is bound [brought together by force] in "freedom, peace and unity." Finally, the line indicates the first motto of Nigeria before 1978, which was "peace, unity, freedom." It also sheds light on why the almost 450 ethnic groups in the colony came together for independence i.e. for freedom, peace and unity. Hence, the illocutionary act of a nation that is bound in freedom, peace and unity is asserting/informing.

From the foregoing, if the whole of stanza one is taken together, this study may conclude that the illocutionary act is summoning/commanding. This is so because all other words in the stanza are justifying the first word i.e. arise which is a clarion call as well as a directive to the natives.

Similarly, the first line of the second stanza is: "Oh God of creation, direct our noble cause." Graphologically, the writer, tactically divided the line into two separate segments with a comma. The illocutionary act of the first part is summoning (God). This fraction is significant to all other aspects of the stanza. It serves as a springboard or an ellipted element, not only to the second segment of the line, but also the rest of the stanza. As a result, this paper can conclude that the writer/composer is praying through the stanza. Thus, the study has "Oh God of creation, direct our..." (line 1), "guide our..." (line 2), "help our..." (line 3). However, it is insightful to note that each line of stanza two also communicates different pragmatic imports. Thus, "...direct our noble cause" (line 1) presupposes the existence of a new or dignified foundation/beginning, which requires divine direction; the absence of the latter can spell doom for the nascent nation. This further suggests that the efforts of the compatriots (summoned in stanza one) are not adequate in governing the burgeoning nation. So, the assistance of the Supreme Being has to be sought in the form of prayer for the collective good of everyone involved in "our noble cause."

In the same vein, "guide our leader's right" (line 2) presupposes the existence of a budding leader ( $\mathrm{s}$ ) who has the tendency to go the wrong 
direction; hence, he needs divine guidance to do what is right. The writer/composer concentrates on the leadership of the nation in line 2, having prayed for every citizen and the country in the previous line. He is requesting God to guide their leader right, hence the illocutionary act of praying or requesting. Meanwhile, line 3 is requesting that God should grant the youths the right knowledge. The words "help our youths the truth to know" presuppose that the youths have been thriving in falsity before. Socially, the clause suggests that as the independent nation is striving to come out of its shell of colonial mentality, the youths need to understand certain truths and social values.

Lines 4 and 5 clarify the truth and social values being raised in line 3 by the addresser. The youth should know that it is in love and honesty that they can grow, as well as by living just and true. These words presuppose a situation where love, honesty and truth are needed. It should be noted that by the time this anthem was composed, Nigeria has experienced one civil war (Biafra War of 1967-1970) and four military coup d'etats. These are Major Kaduna Nzeogwu Coup (January, 1966), General Yakubu Gowon's Counter Coup (July 1966), Generals Murtala/Obasanjo Coup (July, 1975) and Lt Col. Buka Dimka's aborted Coup (February 13, 1976). As of 1978, when this song was composed, General Olusegun Obasanjo was the Head of State. He took over the mantle of leadership after his boss, General Murtala Mohammed was assassinated by Lieutenant Colonel B.S. Dimka on $13^{\text {th }}$ February, 1976. The above situations in the country could generate tension and disaffections, hence the composer's clamour for love, justice and truth. Notwithstanding, rather than telling the people directly, the composer turns his request to prayer before God, thus the illocutionary act of praying.

Finally, the addresser uses the wordings of lines 5 and 7 to intercede for his audience that they should attain great lofty heights such that they would be able to build a nation where peace and justice shall reign. These words suggest that Nigeria has not yet fully developed as a nation. Being a developing country, she needs to grow into an enviable (great lofty) height while simultaneously addressing the issues of injustice, civil unrest and war in order to maintain a peaceful nation. The above locutions are, therefore, subtly introduced into the songs in the form of prayer in stanza 2, hence, the illocutionary act of praying.

The overall perlocutionary act of the anthem is significant. Largely, Nigerians welcome the anthem and they are fond of it more than the former. For instance, when "Nigeria we hail thee" was first introduced, it was greeted with criticism. The protest was reportedly intense that a native newspaper, the Daily Service, which was owned by the Yoruba socio-cultural group Egbe Omo Oduduwa "started a rebellious campaign against the national anthem which led to a committee being established to collect signatures as a petition." 
(see https://en.wikipedia.org/wiki/Nigeria,_We_Hail_Thee Accessed June 4, 2020). But the effect of "Arise O compatriots" is overwhelming. The natives who believed that the former anthem was composed by a Briton saw a ray of hope in the new anthem because it "highlighted their differences...Though tribes and tongues may differ..." (Media Nigeria.com, 2018). Furthermore, the anthem was celebrated because it glorifies the rich culture and heritage of the country. Religiously, the people embraced it so much that it is being sung in churches and mosques, particularly the second stanza which is a prayer. Specifically, it put an end to the Muslim/Christian dichotomy during opening/closing prayers in public places. Media Nigeria.com (2018:1) captures the situation succinctly as follows:

As a matter of fact, the federal executive council in 2012

decided that the second stanza should be the official national prayer and was to replace the separate Christian and Muslim prayers often offered at official gatherings and events. Overall, the Nigerian anthem... is indeed the dream of every citizen of this great nation.

From the analysis so far, we may establish that the writer/composer is praying preponderantly in (stanza two of) the anthem such that we have "Oh God of creation, direct our... (line 1), guide our...(line 2), help our...(line 3)." Socially, this is the system in Africa where prayer either precedes or ends an endeavour. It further bolsters the biblical saying, "work and pray." The writer/composer, therefore, summons his compatriots (humanity) to arise in stanza one before calling on God, the creator (divinity) to guide, direct and help the people as well as the country in the second stanza.

\section{Statistical Analysis:}

The analysis above is captured in table 1 below.

Table 1: Speech acts distribution in the anthem

\begin{tabular}{|l|l|}
\hline Locutionary Act & Illocutionary Act \\
\hline $\begin{array}{l}\text { *Arise, O compatriots, Nigeria's } \\
\text { call obey }\end{array}$ & Summoning/commanding \\
\hline To serve our fatherland & Informing \\
\hline With love and strength and faith & Describing/informing \\
\hline
\end{tabular}




\begin{tabular}{|l|l|}
\hline $\begin{array}{l}\text { The labour of our heroes past; } \\
\text { shall never be in vain }\end{array}$ & Reminiscing/asserting \\
\hline To serve with heart and might & Admonishing/justifying \\
\hline $\begin{array}{l}\text { One nation bound in freedom, } \\
\text { peace and unity }\end{array}$ & Asserting/informing \\
\hline $\begin{array}{l}* * \text { Oh God of creation, direct our } \\
\text { noble cause }\end{array}$ & Summoning/praying \\
\hline guide our leader's right & Praying/requesting \\
\hline Help our youth the truth to know & Praying \\
\hline $\begin{array}{l}\text { In love and honesty to grow, and } \\
\text { living just and true }\end{array}$ & Praying \\
\hline $\begin{array}{l}\text { Great lofty heights attain } \\
\text { and justice shall reign. }\end{array}$ & Praying \\
\hline To build a nation where peace & Praying \\
\hline
\end{tabular}

In table 1 the single asterisk $(*)$ indicates the commencement of stanza one and double asterisks (**) stand for the beginning of the second stanza. Thus, the table indicates the two stanzas of the anthem, each having six lines, based on the present analysis. This translates to a total of twelve lines. Each line signifies the locutionary act(s) and its attendant illocutionary act(s). The illocutionary acts frequency(ies) and percentage(s) are represented in table 2 as follows: 
Table 2: Frequency and percentage of illocutionary acts

\begin{tabular}{|l|l|l|l|}
\hline S/N & Illocutionary Act(s) & Frequency & Percentage \\
\hline 1. & Summoning & 2 & 16.66 \\
\hline 2. & Informing & 3 & 25 \\
\hline 3. & Asserting & 1 & 8.33 \\
\hline 4. & Admonishing & 1 & 8.33 \\
\hline 5. & Praying & 5 & 41.66 \\
\hline & Total & 12 & 100 \\
\hline
\end{tabular}

Table 2 indicates that five different illocutionary acts are deployed. Although we have situations in which one datum showcases two illocutionary acts as indicated in table 1, we pick on the dominant illocutionary act in such a situation. For example, summoning is considered the major illocutionary act in the first line(s) of each of the two stanzas. Therefore, we may submit that among the illocutionary acts deployed, praying has the highest frequency of five $(41.66 \%)$. It is followed by informing which has three as its frequency (25\%). Summoning appears twice $(16.66 \%)$ while both asserting and admonishing have one frequency each, hence $8.33 \%$ respectively. This situation is represented with a line chart in Fig. 1 as follows:

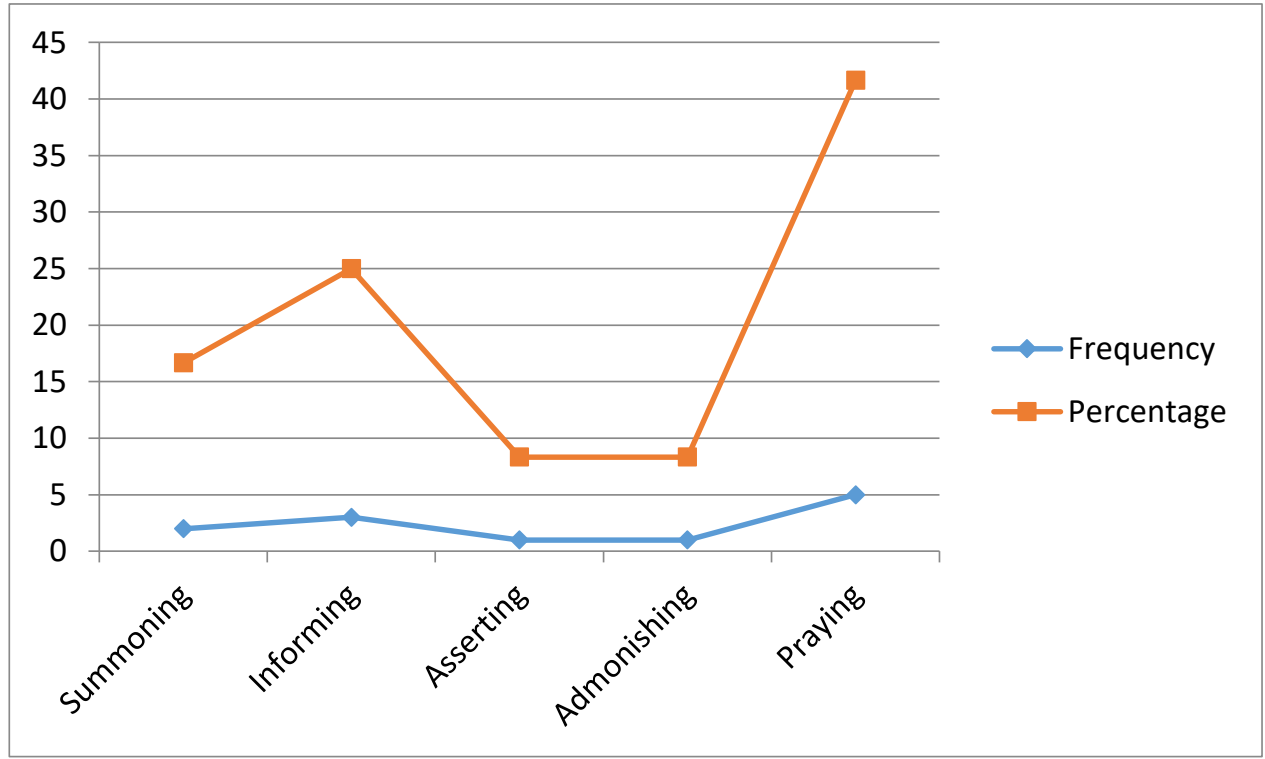

Fig. 1: A line chart indicating the frequency and percentage of illocutionary acts in the anthem 
A further dissection of the above indicates that virtually all the verbs in the text are constatives. Based on Austin's taxonomy, the verbs can be classified as follows:

Table 3 (a and b): Austin's Classification of Verbs in the Anthem (a.) Stanza One:

\begin{tabular}{|l|l|l|}
\hline Line & Verb (Locution) & Speech Act \\
\hline 1. & Arise... & Excersitive \\
\hline 1. & $\ldots$ obey & Excersitive \\
\hline 2. & To serve & Behavitive \\
\hline 5. & Shall never & Verdictive \\
\hline 6. & To serve & Behavitive \\
\hline
\end{tabular}

In stanza one, two verbs (arise and obey) are foregrounded in the first line. These, by Austin's classification, have the illocutionary undertone of excersitives, because they are both ordering or commanding. Searle (1969) classifies such verbs as directives. Line 2 features "to serve" which is behavitives. The verb in line 5 is "shall..be.." and it is a future tense asserting that the labour of the past heroes shall never be in vain; hence, it is assertive according to Austin's taxonomy. However, such a verb is classified by Searle as declarative. The last constative verb in stanza one is found in line 6. It is a non-finite verb "to serve." Since it predicts a kind of social attitude/behavior among the participants, it is considered a behavitive.

\section{(b) Stanza Two}

\begin{tabular}{|l|l|l|}
\hline Line & Verb (Locution) & Speech Act \\
\hline 1. & (O God) ...direct & Excersitive \\
\hline 2. & Guide & Excersitive \\
\hline 3. & Help $\ldots$ & Excersitive \\
\hline 4. & To grow & Behavitive \\
\hline 5. & And living & Behavitive \\
\hline 6. & $\ldots$ attain & Behavitive \\
\hline 7. & To build & Behavitives \\
\hline 7. & *...shall reign & $\begin{array}{l}\text { Behavitives/ } \\
\text { Verdictive } \\
\text { (*predictive, Allan, 1986) }\end{array}$ \\
\hline
\end{tabular}


In the same vein, stanza 2, lines 1, 2 and 3 feature excersitives. These are direct (line 1), guide (line 2) and help (line 3) respectively. Following the triad is a quatrain of lines 4 to 7 which feature behavitives thus: the infinitival verbs "to grow" (line 4) and "living" (line 5), "attain" (line 6) and the infinitive "to build" (line 7). The last verb (shall reign) in line 7 is a future tense. Based on Austin's classification, we may argue that it is both verdictive and behavitive. It is verdictive because it is giving a verdict or an appraisal on the hereafter. Thus, after the addressees have carried out everything said by the addresser, justice shall reign. Alternatively it is behavitive because it predicts an action, a social behavior and attitude of the addressees. This is what Allan (1986) calls a predictive speech act.

Table 4: Summary of Austin's Classificatory Paradigm

\begin{tabular}{|l|l|l|}
\hline Speech Act Typology & Frequency & Percentage \\
\hline Behavitives & 6 & $\mathbf{4 6 . 1}$ \\
\hline Excersitives & $\mathbf{5}$ & $\mathbf{3 8 . 4}$ \\
\hline Verdictive & 2 & 15.3 \\
\hline Total & 13 & 100 \\
\hline
\end{tabular}

Table 4 gives the summary of Austin's speech act classification as applicable to the verbs our text. Three major acts are deployed, namely behavitives, excersitives and verdictives. Behavitives have six frequency (46.1\%) Excersitives have five (38.4\%) and verdictives, two (15.3\%). This is represented by a bar chart in fig. 2 . 


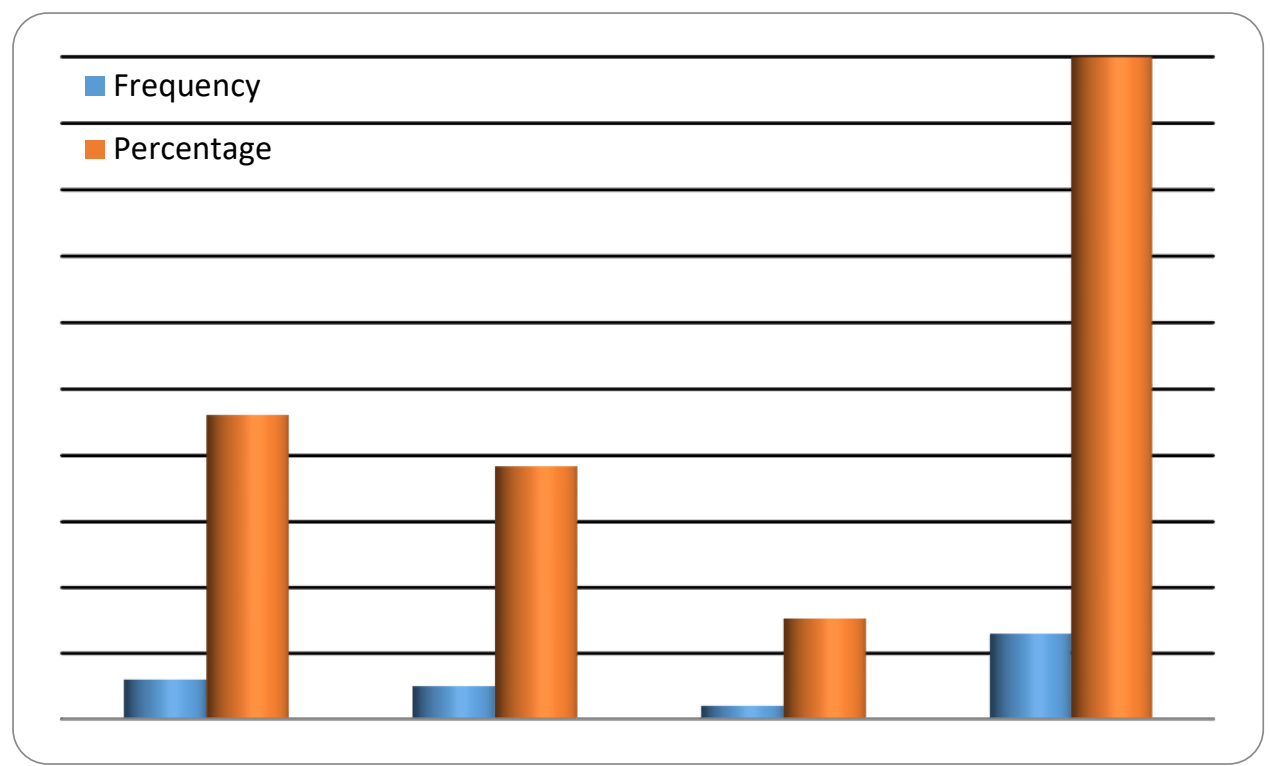

Fig.2: Bar chart indicating frequency and percentage of Austin's speech acts

\section{Conclusion}

The analysis above indicates that the (new) Nigerian national anthem is not just designed as an ordinary political song. Pragmatically, it is intended for praying and informing the Nigerian populace. The writer/composer also uses the medium to summon and admonish the citizens on their historical past as well as the need to arise to duties for the betterment of the nation. Stylistically, stanza one is addressed to men while stanza two is addressed to God. Politically, the song brings about cohesion in the Nigerian nation which has about 450 heterogeneous communities and languages. That is why it is largely sung in English, the official language (cum lingua franca) of the country, despite its translation to only three dominant languages (Hausa, Yoruba, Igbo),

A further distribution of the verbs in the text based on Austin's (1962) taxonomy indicates a preponderance of behavitives and excersitives with just few verdictives. Ideationally, the text presents the worldview of Nigeria as an independent nation. Interpersonally, the song serves as a means of sustaining social cohesion and interaction in the country. Finally, the anthem functions textually as a means of constructing 'texts' that are coherent and situationally relevant in socio-political discourse (Halliday 1973, p.41).

Thus, we may conclude that the writer/composer is praying preponderantly in the anthem such that we have "Oh God of creation, direct our... (line 1), guide our...(line 2), help our...(line 3)." Socially, this is the system in Africa where prayer either precedes or ends an endeavour. It further buttresses the biblical saying, "work and pray." Thus, the writer/composer 
summons his compatriots (humanity) to arise in stanza one before calling on God, the creator (divinity) to guide, direct and help the people as well as the country in the second stanza.

\section{References:}

1. Adegbite, W. (2009). Language, gender and politics: A general perspective. In Language, gender and politics. Odebunmi, A., Arua E. \& Arimi, S. eds. Lagos: Concept Publications limited. Pp. 9-21.

2. Allan, K. (1986). Linguistic meaning vols. I\&II. London: Routledge and Kegan Paul Plc.

3. Austin, J.L. (1962). How to do things with words. Oxford: Oxford University Press.

4. Bell, A. (1984). Language style as audience design. In Coupland, N. and Jaworsky, A. (eds.) Sociolinguistics: a reader and course book. New York: St Mattin's Press Inc. Pp. 240-250.

5. Chilton, P. (2004). Analysing political discourse: Theory and practice. London and New York: Routledge.

6. Faniyan, G. (2012). A stylistic analysis of the Nigerian national anthem and pledge, In https:/gabrielfaniyan.wordpress.com/2012/08/07/a-stylistic-analysisof-the-nigerian-national-anthem-and-pledge/ Accessed on April 30, 2020.

7. Giles, H., Coupland, J. \& Coupland, N. (1991). Accommodation theory: Communication, context and consequence. In Contexts of accommodation ed. Howard Giles, Justine Coupland, Nikolas Coupland. Cambridge University Press. Pp 1-68.

8. Halliday, M.A.K. (1970). "Language Structure and Language Function" in J. Lyons (ed.) New Horizons in Linguistics. Harmondsworth: Penguin Books pp. 140-165.

9. (1973). Explorations in the Functions of Language. London: Edward Arnold.

10. Matthiesen, C. M. I. M. (2004). An Introduction to Functional Grammar, 3rd edn, London: Arnold. https://www.google.com/search?client=firefox-b $\mathrm{d} \& \mathrm{q}=$ nigeria+the + most + populous+country+in+africa. Accessed May 2, 2020.

11. Malmkjaer, K. (2002). Speech act theory in Malmkjaer, K. ed. The linguistics encyclopedia, second edition. London and New York: Routledge. Pp. 486-495.

12. Media Nigeria.Com (2018). History of Nigerian National Anthem. In https://www.medianigeria.com/history-of-nigerian-national-anthem/ Accessed June 4, 2020. 
13. Mohammed, I. \& Ayeni, E. (2018). Political leadership in Nigeria: Our national anthem and national pledge. Journal of Pan African Studies.

14. 12(1) In https://www.questia.com/library/journal/1G1559893758/political-leadership-in-nigeria-our-national-anthem. Accessed April 30, 2020.

15. Nigerian national anthem (www.doc) in http://www.nigeriahc.org.uk/national-anthem Accessed April 13, 2020.

16. Nigeria we hail thee (online) In https://en.wikisource.org/wiki/Nigeria_We_Hail_Thee Accessed April 13, 2020.

17. Odebode, I. and Okunlola, T. (2018). Speech acts in Goodluck Jonathan's inaugural speech. In Osisanwo, A., Olaosun, I. and Odebode, I. eds.

18. Discourse-stylistics, sociolinguistics and society. Ibadan: StirlingHorden Publishers Ltd. Pp. 532-543.

19. Ogunsiji, A. (2018). The power and politics of language: the challenges of language policies and choice in the multilingual Nigerian setting. In Osisanwo, A., Olaosun, I. and Odebode, I. eds. Discoursestylistics, sociolinguistics and society. Ibadan: Stirling-Horden Publishers Ltd. Pp. 547-565.

20. Osisanwo, W. (2003). Introduction to discourse analysis and pragmatics. Lagos: Femolus-Fetop Publishers.

21. Oyeleye, A.L. (1985). "The Language of Achebe's Early Novels (in the Context of Nigerian English). A Study in Literary Stylistics". Unpublished Ph.D. Thesis, University of Ife, Ile-Ife, Department of English.

22. Oyeyemi, A.S. (2018). The Nigeria's national anthem: A Text Linguistic Exploration. International Journal of English Language and Linguistics Research 6(1), 31-38.

23. Searle, J.R. (1969). Speech acts: An essay in the philosophy of language. Cambridge: Cambridge University Press 


\section{Appendix One}

Nigerian National Anthem

1. Arise, O compatriots, Nigeria's call obey

To serve our fatherland

With love and strength and faith

The labour of our heroes past

Shall never be in vain

To serve with heart and might

One nation bound in freedom, peace and unity.

2. Oh God of creation, direct our noble cause

Guide our leader's right

Help our youth the truth to know

In love and honesty to grow

And living just and true

Great lofty heights attain

To build a nation where peace and justice shall reign.

\section{Appendix Two}

Nigeria We Hail Thee (Old National Anthem)

1. Nigeria, we hail thee,

Our own dear native land,

Though tribe and tongue may differ,

In brotherhood we stand,

Nigerians all, are proud to serve

our sovereign motherland.

2. Our flag shall be a symbol, That truth and justice reign, In peace or battle honoured, And this we count as gain To hand on to our children

A banner without stain

3. O Lord of all creation,

Grant this our one request

Help us to build a nation

Where no man is oppressed

And so, with peace and plenty,

Nigeria may be blessed 